\title{
Social Policy and Society
}

\section{Guidelines for Contributors}

Please find the detailed guidelines at:

https://www.cambridge.org/core/journals/social-policy-and-society/information/instructions-contributors

\section{The Social Policy Association}

The Social Policy Association supports the study of all aspects of Social Policy through the sponsorship of its journals (the Journal of International and Comparative Social Policy, the Journal of Social Policy and Social Policy and Society), the publication of a newsletter, the organisation of an annual conference and a small grants scheme. It represents its members through contact with a range of bodies, including the ESRC. For further information about the activities of the SPA, contact: Rachael Dobson, School of Psychology, Criminology and Sociology, Faculty of Arts and Social Sciences, Kingston University, Penrhyn Road Campus, Kingston upon Thames, Surrey KT1 2EE. 


\section{: SOCIAL POLICY AND SOCIETY \\ L THEMED SECTION: POLICIES AND PRACTICES SHAPING LONG-TERM \\ U CARE: BETWEEN AN INCLUSIVITY ETHOS AND SERVICE DELIVERY \\ M REALITIES \\ E}

\section{CONTENTS}

\section{ARTICLES}

RONI HOLLER and AVISHAI BENISH

Into the Promised Land: Modelling the Role of Take-Up Agents in

P Realising Welfare Rights

A ANDREA WIGFIELD, ROYCE TURNER, SARAH ALDEN, MARCUS GREEN and

R VINAL K. KARANIA

T Developing a New Conceptual Framework of Meaningful Interaction for Understanding Social Isolation and Loneliness

TIINA SIHTO

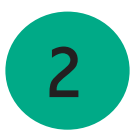

Dividing Responsibility for Care: Tracing the Ethics of Care in Local Care Strategies AXEL CRONERT

The Multi-Tool Nature of Active Labour Market Policy and its Implications for Partisan Politics in Advanced Democracies

MELANIE HENWOOD, JON GLASBY, STEVE MCKAY and

CATHERINE NEEDHAM

R Self-funders: Still By-Standers in the English Social Care Market?

MARY LARKIN, MELANIE HENWOOD and ALISOUN MILNE

L Older Carers and Carers of People with Dementia: Improving and Developing

Effective Support

THEMED SECTION

THEMED SECTION: POLICIES AND PRACTICES SHAPING

LONG-TERM CARE: BETWEEN AN INCLUSIVITY ETHOS AND SERVICE DELIVERY REALITIES

Guest Editors: SHEREEN HUSSEIN, AND SARA CHARLESWORTH

Introduction

DANIEL ROLAND, JULIEN FORDER and KAREN JONES

State of the Art: What Is Out There and What Can We Learn? International

Evidence on Funding and Delivery of Long-Term Care

JONAS LINDBLOM and SANDRA TORRES

Othering in Media Representations of Elderly Care: Using the Social Justice Framework to Make Sense of Public Discourses on Migrants and Culture

ROBIN A. DARTON

Extra Care Housing: The Current State of Research and Prospects for the Future

STEPHEN ALLAN and ROBIN DARTON

Incentives and Deterrents to the Supply of Long-term Care for the Elderly in England:

Evidence and Experience in Two Local Authorities

SHEREEN HUSSEIN

Employment Inequalities Among British Minority Ethnic Workers in Health and

Social Care at the Time of Covid-19: A Rapid Review of the Literature

SHEREEN HUSSEIN and SARA CHARLESWORTH

Some Useful Sources 